\title{
電解によるアゾ染料の分解に及ぼすハロゲンイオンの効果*1
}

\author{
熊本県立大学生活科学部 深津和彦 \\ クイーンズランド工科大学 S. Kokot
}

\section{Effects of Halogen Ions on Degradation of Azo Dyes with Electrolysis*1}

\section{Kazuhiko Fukatsu*2 and Serge Kokot ${ }^{* 3}$}

*2 Faculty of Life Sciences, Prefectural University of Kumamoto, Tsukide Kumamoto, 862 Japan

*3 Centre for Instrumental and Developmental Chemistry, Queensland University of Technology. Bris. bane, QLD, 4001 Australia

\begin{abstract}
The degradation of azo dyes such as Orange $I \sim \mathbb{N}$ was investigated in an electrolyte solution containing chloride or bromide ions as halide ions with electrolysis. In the presence of halide ions, the electrolyzed degradation was accomplished because of the generated electrophilic halonium ions as active species with electrolysis that involve initial attack at azo groups. It was presumed that these degradations were due to the molecular structure of dyes relating to the existence of azo-hydrazone equilibria in hydroxyazo dyes and electron-donating group in aminoazo dyes. In the case of an electrolyte solution containing chloride ion, the degradation of dyes was significantly influenced by the $\mathrm{pH}$ of this electrolyte and decrease with rising $\mathrm{pH}$. The ability of degradation with electrolysis was larger in bromide ion than that in chloride ion and the $\mathrm{pH}$ of electrolyte had no influence on the degradation in the case of bromide ion, compared with chloride ion.
\end{abstract}

(Received April 17, 1996)

\section{1. 粕言}

綿織物の過酸化水素漂白において，しばしば起こる損 借について Meyer ら[1]は，䄸織物中に微量含まれる鉄 等の金属イオンが過酸化水素分解の触媒として作用し， 生成する活性種がセルロースに損傷を与えるメカニズム を提案し，Kokotら[2-4]はこの損傷モデルとして電気 化学的手法を検討し，綿織物は陰極では損傷を受けない ものの，陽極におういては電極との接触面で著しく損傷を 受けることを報告した。この電気化学的な損傷が起こる 理由として，陽極で生成する活性酸素種がセルロースを 攻撃するメカニズムを過酸化水素漂白による損傷と比較 し, 提案した。

本研究は電解により生成する活性種を綿織物の漂白に

*1この報文を「電解発生酸素による綿織物の漂自に関す る研究 (第 3 報)；Bleaching of Cotton Fabric by Elec tro-Generated Oxygen（Part 3)」とする。
応用する第一歩として，塩素イオンを含む支持電解質溶

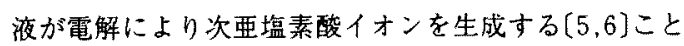
に注目し，電解による水溶性アゾ染料の分解について検 討した。次覀塩素酸イオンによる染料の分解については， Gregory ら[7]が，次亜塩素酸ナトリウムに上る水溶性 アゾ染料の分解について，染料の化学構造との関連を詳 細に検討し，染料のアゾ型とヒドラゾン型の間の互変異 性平衡が染料の分解に大きな影響を与え，ヒドラゾン型 の $\beta$-窒素原子が攻撃を受けやすく，その攻整種は次亜 塩素酸ナトリウムから生成するクロロニウムイオン $\left(\mathrm{Cl}^{+}\right)$であると報告した。また，この互変異性平衡の染 料分解性への関与については, Griffitsh ら[8]によりア ゾ染料のアゾーヒドラゾン互变異性平衡が一重項酸素に よる酸化においても，大きく影響することが示された。

電解による染料の分解に関する系統的な報告はほとん ど見られないので，染料としてオレンジ I ー IVの 4 種の 水溶性アソ染料を用い，電気化学的分解に拀ける八ロゲ ンイオンの影響についての知見を得るため，電解液中に 
塩素，景素、ヨウ素イオンを添加し梌討を行った。また， これら染料の分解について，染料の化学構造との関連に ついてむ，著干の検討を行った。

\section{2. 実梌}

\section{1 染料および試薬}

水溶性アゾ染料は，ヒドロキシアゾ染料（HAと略す） としてオレンジIとI，アミノアゾ染料 (AAと略す) としてオレンジ四とNのそれぞれ市服試薬特級品を用い た。使用前に，水一エタノールでの再結晶を繰り返した 後，展開郕としてピリジン (30)-水 $(70)$ 混合溶媒を 用いて，シルカゲル薄層クロマトグラフィーで純度を確 韵した。これら染料の化学棈造式と水溶液 $(\mathrm{pH} 6.8)$ 中 での可梘部に扔ける最大吸収波長を図1に示した。試薬 は市販特級品をそのまま使用し，水は市販試薬精製水を

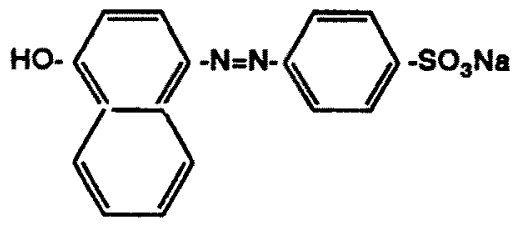

Orange I $\lambda \max =495 \mathrm{~nm}$

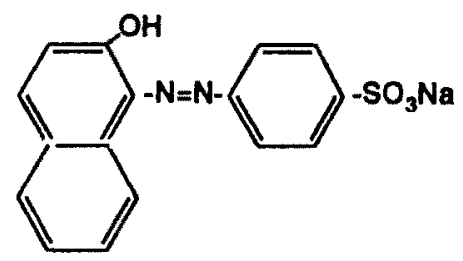

Orange II $\lambda \max =485 \mathrm{~nm}$<smiles>CN(C)c1ccc(N=Nc2ccc(S(=O)(=O)[O-])cc2)cc1</smiles>

Orange III $\lambda \max =478 \mathrm{~nm}$

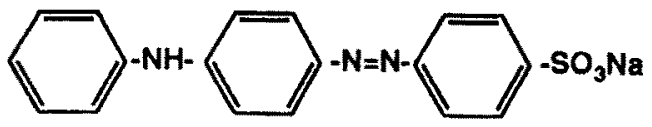

\section{Orange IV $\lambda \max =460 \mathrm{~nm}$}

Fig. 1 Molecular structure and maximum absorption wavelength in aqueous solution $(\mathrm{pH} \mathrm{6.8)}$ of azo dyes used.
用いた。

\section{2 電解溶液の歌然}

種々の $\mathrm{pH} の$ 楥衝溶液 $(\mathrm{pH} 3.2 \sim 6.6 ; 1 / 10 \mathrm{~N}$ 酢酸 -1/10M 酢酸ナトリウム, $\mathrm{pH} 6.8 \sim 8.0 ; 1 / 15 \mathrm{M} リ ン$ 酸 二水素力リウム $-1 / 15 \mathrm{M}$ リン酸水素二ナトリウム, $\mathrm{pH}$ 9.2〜11.0；1/20 M ホウ砂-1/20 M 炭酸ナトリウム）を 調製した。これらの緩衝液を用いて0.1 M ハロゲン化力 リウム水溶液を調製し，電解㴼液として用いた。

\section{3 染料水溶㳔の䉓解}

雨極に白金線（長ざ $60 \mathrm{~mm} \times$ 径 $0.5 \mathrm{~mm}$ ）を電極として

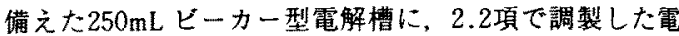
解溶液 $190 \mathrm{~mL}$ を入れ，さらに2 $2 \times 10^{-3} \mathrm{M}$ 染料水溶液 $10 \mathrm{~mL}$ を添加し，染料濃度 $1 \times 10^{-4} \mathrm{M}$ の溶液を解製した。 電源装置（アドバンテック東洋製エレポス PS-520D） を用いて，電解槽を鄮拌しながら，定電流40mA，温度 $30^{\circ} \mathrm{C}$ のとで10分間電解索行った。

\section{4 染料水溶游の分解曲線}

光路長 $1 \mathrm{~cm}$ 石英ガラス製七ミマイクロフローセル を接続した定量ポンプ(イワキ製ペリスタリーポンブ PST-100）を用い，電解槽溶液を流量 $12 \mathrm{~mL} / \mathrm{min}$ で循環 己せ，分光光度計（扁津製UV-160A）でそれぞれの染 料の最大吸收波舞に扔ける吸光度を連続的に測定した。 極大吸收波長に㧍ける吸光度 (At) が，初期吸光度 (Ao)の半分になるまでの時間 (min) を吸光度の半隇 值（t1/2）として分解速度の指標に用いた[7]。また，必 要に応して波長300－600nmにおける吸収スペクトルを 測定した。

\section{3. 結果およぴ考察}

アゾ染料の電解による分解性を娭討するため，オレン $\forall \mathrm{I}$ - IV 4 種の染料溶液（濃度 $1 \times 10^{-*} \mathrm{M}$ ) を種々 の $\mathrm{pH}$ で電解を行った。電解により瀻維の損稘が起こる ことが知られており(2)，耭維の損稘をできる隄り防ぐ 意味で，比較的温和な電解条件（定電流 $40 \mathrm{~mA}$, 温度 $30^{\circ} \mathrm{C}$ ）を採用した。表 1 に，電解溶液にハロゲンイオン を含まない場合の電解時間に対する最大吸収波長におけ る吸光度の变化を示す。いずれの染料も測定特間（10分 間）の範囲では，pHにも影翠されることなく，ほとん ど分解は認めら机なかった。また，吸取スペクトルにも 变化杜見られなかった。夷に，ハロゲンイオンとして程 素，奥素执よびヨウ素イオンの分解への影智について検 討を行った。しかし，ヨウ素イオンに拟ては，電解に より陽極表面にヨウ素が析出するためコウ素イオンの検 討は，本研究では見合わせた。

図 2 に, 塩化カリウムを電解溶液に添加し，ハロゲン イオンとして塩素イオン（濃度 $0.1 \mathrm{M}$ ) を共存させた $\mathrm{pH}$ 
Table 1 Degradation of Orange $\mathrm{I} \sim \mathrm{N}$ in Various $\mathrm{pHs}$ with Electrolysis under a Constant Current of $40 \mathrm{~mA}$ at $30 \mathrm{C}$ in the Absence of Chloride lon

\begin{tabular}{|c|c|c|c|c|}
\hline & Dye & & Absorbance & \\
\hline & Orange & $A_{0}(0 \mathrm{~min})$ & $A_{t}(10 \mathrm{~min})$ & $A_{1} / A_{0}$ \\
\hline \multirow{4}{*}{$\mathrm{pH} 3.8$} & I & 1.93 & 1.90 & 0.984 \\
\hline & II & 1.22 & 1.20 & 0.984 \\
\hline & III & 1.86 & 1.85 & 0.995 \\
\hline & IV & 1.55 & 1.54 & 0.994 \\
\hline \multirow{4}{*}{$\mathrm{pH} 6.8$} & I & 1.91 & 1.90 & 0.995 \\
\hline & II & 1.21 & 1.20 & 0.992 \\
\hline & III & 1.83 & 1.83 & 1.00 \\
\hline & IV & 1.58 & 1.58 & 1.00 \\
\hline \multirow{3}{*}{$\mathrm{pH} 10$} & II & 1.18 & 1.18 & 1.00 \\
\hline & III & 1.75 & 1.73 & 0.989 \\
\hline & N & 1.52 & 1.52 & 1.00 \\
\hline
\end{tabular}

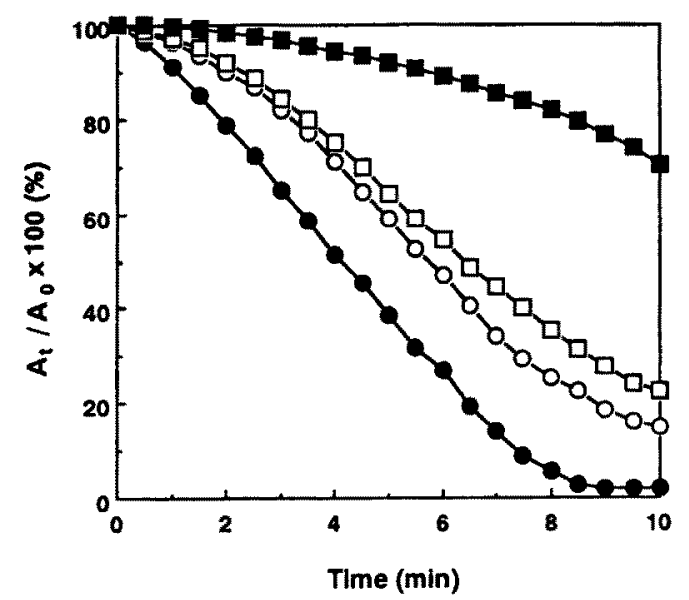

Fig. 2 Degradation curves for Orange $I-N$ in $0.1 \mathrm{M}$ $\mathrm{KCl}$ solution ( $\mathrm{pH} 6.8$ ) with electrolysis under a constant current of $40 \mathrm{~mA}$ at $30{ }^{\circ} \mathrm{C}$ (initial concentration of dyes $\left.=1 \times 10^{-4} \mathrm{M}\right): \mathrm{O} ;$ Orange I, O Orange II, $\square ;$ Orange III, $\mathbf{D}$; Orange $\mathbb{N}$.

6.8 の溶液における吸光度の減少率 $\left(\mathrm{A}_{\mathrm{t}} / \mathrm{A}_{0} \times 100\right)$ と時 間との関係を表す分解曲線を示す。いずれの染料におい ても分解が見られ，最大吸収波長にお忛る吸光度の減少 度合は，オレンジ II $>I \geqq I I>\mathbb{N}$ の順に大きく，染料の 化学構造が分解速度に大きく影響することが示啳された。 Rajeshwar ら[6]は，塩素イオンの存在下において電解 を行うと，次亜塩素酸イオンが陽極で次式により生成す

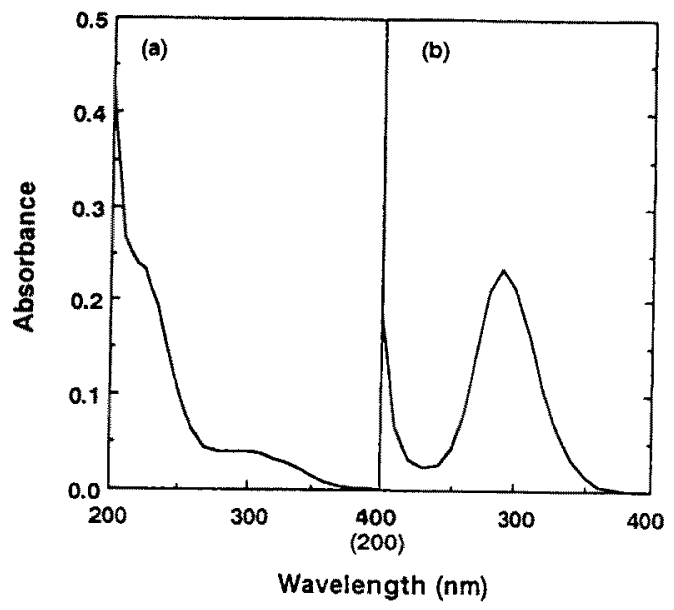

Fig. 3 UV spectra of $0.1 \mathrm{M} \mathrm{KCl}$ electrolyte solution electrolyzed with a Pt electrode under a constant current of $40 \mathrm{~mA}$ at $30^{\circ} \mathrm{C}$ in pH $3.8(\mathrm{a})$, and $10(\mathrm{~b})$.

ることを報告している。

$$
\begin{aligned}
& 2 \mathrm{Cl}^{-} \rightarrow \mathrm{Cl}_{2}+2 \mathrm{e}^{-} \\
& 4 \mathrm{OH}^{-} \rightarrow \mathrm{O}_{2}+2 \mathrm{H}_{2} \mathrm{O}+4 \mathrm{e}^{-} \\
& \mathrm{Cl}^{-}+2 \mathrm{OH}^{-} \rightarrow \mathrm{OCl}^{-}+\mathrm{H}_{2} \mathrm{O}+2 \mathrm{e}^{-} \\
& \mathrm{Cl}_{2}+2 \mathrm{OH}^{-} \rightarrow \mathrm{OCl}^{-}+\mathrm{Cl}^{-}+\mathrm{H}_{2} \mathrm{O}
\end{aligned}
$$

本研究において図 3 に示すように，塩素イオンの電解 により pH 3.8で220nmにショルダーを, pH 10では $290 \mathrm{~nm}$ に最大吸収を持つ吸収スペクトルを示し、これ らの吸収は電解時間とともに增大した。また, 次亜塩素 酸イオンの吸取スペクトルは酸，アルカリにより同様の 変化を示し，H型電解槽による電船で陽極では染料溶液 の分解が見られるが、陰極ではほとんど分解が見られな いことから，本研究の電解でも次亜塩素酸イオンが生成 することは明かであり、この電解による染料の分解は, 生成する次亜塩素酸イオンによるものと考えられる。ア ソ系染料の発色は, 電子吸引基と電子供与基がアゾ基に より連結された分子内電荷移動型の発色系である。次严 塩素酸イオンによる染料の退色はこの発色系の分解によ るものであり，そのメカニズムはアゾ基の $\beta$ 一掌素原子 へ親電子性のクロロニウムイオンの攻撃により不安定な N-クロロヒドラソン中間体が生成し，最終的には分解 生成物としてジアソンウム塩およびキノン誘導体が得ら れるとされている[7]。このクロロニウムイオンの生成 は次业塩素酸イオンから次式に従って生成し，その生成 は $\mathrm{pH}$ に大さ依存し，pHが低いほど生成量は多くな ると言われている[9]。 


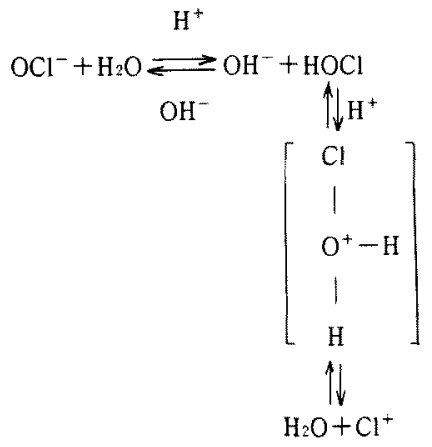

また，塩素イオンの電解により，陣極でクロロニウムイ オンが生成することが知られている(10)。
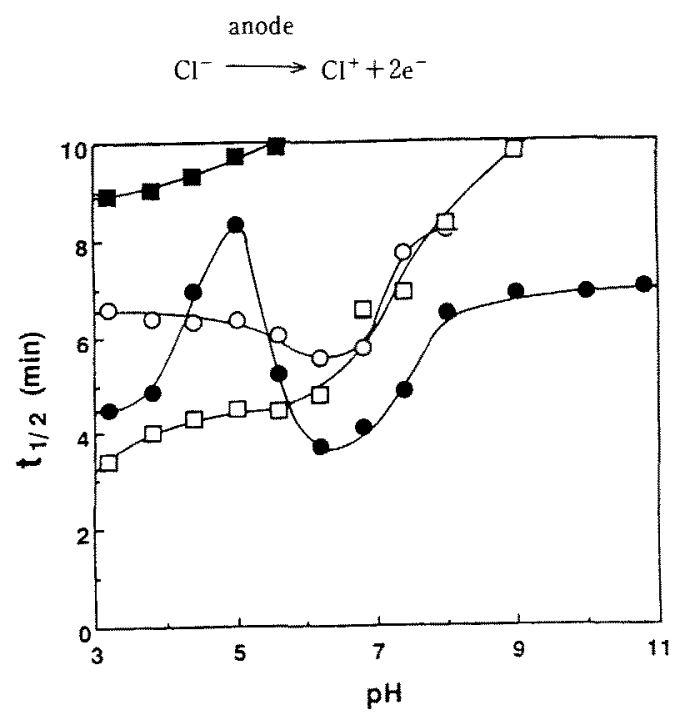

Fig. 4 Relationship between half-life ( $t / 2$ ) for degradation and $\mathrm{pH}$ in degradation of Orange $\mathrm{I} \sim \mathrm{N}$ (initial concentration of dyes $=1 \times 10^{-4} \mathrm{M}$ ) with electrolysis under a constant current of $40 \mathrm{~mA}$ at $30^{\circ} \mathrm{C}$ in the presence of $0.1 \mathrm{M} \mathrm{KCl}: O$; Orange I, $\mathrm{O}$; Orange II, $\square$; Orange III, $\mathbf{O}$; Orange $\mathrm{N}$.

図 4 に，壏素イオン存在下における染料の分解速度に およぱす $\mathrm{pH} の$ 影翌を示す。オレンジII，III，Nは、本 研究の測定 $\mathrm{pH}$ 範囲において最大吸収波長など吸収スぺ クトルに大きな変化は具られなかったが,オレンジIは pH 8 を越えると吸収スペクトルが著しく変化するため, pH 8 以上におけるオレンジIの分解は娭討しなかった。 分解は pHの影翌を大きく受け，ヒドロキシアゾ染料で あるオレンジ I と』は， $\mathrm{pH}$ 增加にともない複雑な挙動
を示した。オレンジIは，pH增加とともに で若干分解速度が増大する傾问にあるが，さらに 增加すると墄少を示した。一方オレンジ Iは $\mathrm{pH} の$ 影 幚を大きく受け，pH增加にともない 速度が減少し，は佂 $\mathrm{pH} 5$ 付近を極大にして pH6 付近ま で分解速度が増大し，その後再度分解速度が咸少する举 動を示した。pH 6 以上での分解速度の城少は，pH增加 にともなうクロロニウムイオン生成量の減少によるもの と考えられる。オレンジII㥛大值付近の $\mathrm{pH}$ 領域を除 きオレンジIに比べて分解されやすく，この違いは染料 の化学構造が分解性の大小に大きく関与していることを 示唆している。Gregory ら[7]の結果からすれば，アソ 型として存在するAAの分解速度は著しく遅くなるもの と子想されるが，AAであるオレンジ四とIとではNの 分解は著しく逛いものの，而の分解はHAの分解とそれ ほど変りないことがわかった。本研究において、HAと AA 間の分解性をアゾーヒドラゾン互変異性平衡で説明 することは醮しいが，HA（オレンジIとI）間および AA（オレンジ四とW）間それぞれの分解性の違いにつ いては，次の様に考えられる。

水酸基をアリールアソ残基のオルトまたはパラ位に持 つ多くのHAは，アゾーヒドラゾン型互变異性平衡にあ ることがよく知られており，また，ヒドラゾン型がアソ 型に比ベてクロロニウムイオン，一重項酸素，ヘルヒド ロキシイオンの攻撃索受けやすく，分解されやすいこと

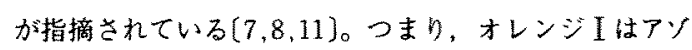
基に対してパラ位に，オレンシリはオルト位に水酸基を 持つアリールアゾナフトール染料であり，いずれもアソ 一ヒドラゾン型互変異性体が存在する。一般に、oーヒド ロキシアソ染料は ラゾン型が倎勢であるといわれており，またオルト効果 も加和り，ヒドラソン型が優勢であるオレンジIIの分解 速度がオレンジ【に比べて大きくなったものと考えられ る。しかし，pH 5 付近でオレンジIIの分解が著しく㨔 少哱る理由については，本表験では不明てあり今後詳細 な検討が必要である。

AAであるオレンジ国とNは $\mathrm{pH}$ の增加にともなって， 分解速度の減少がみられた。これは， $\mathrm{pH} の$ 增加により クロロニウムイオンの生成量が隇少寸るためと考えられ る。オレンジ四と、との分解性の違いに゙ついては、特に オレンジNではタロラミン誘導体の生成か関与している とも考えられる。クロラミンが生成すればオレンジ目， Nの吸収スペクトルの経時变化に大きな差異が認められ るはずでる。しかししながら，オレンジNの吸收スペク トルの経時変化には，電解により $360 \mathrm{~nm}$ 付近に等吸収 点を示しながら、最大吸収渡長が徐々に低波長側に約 


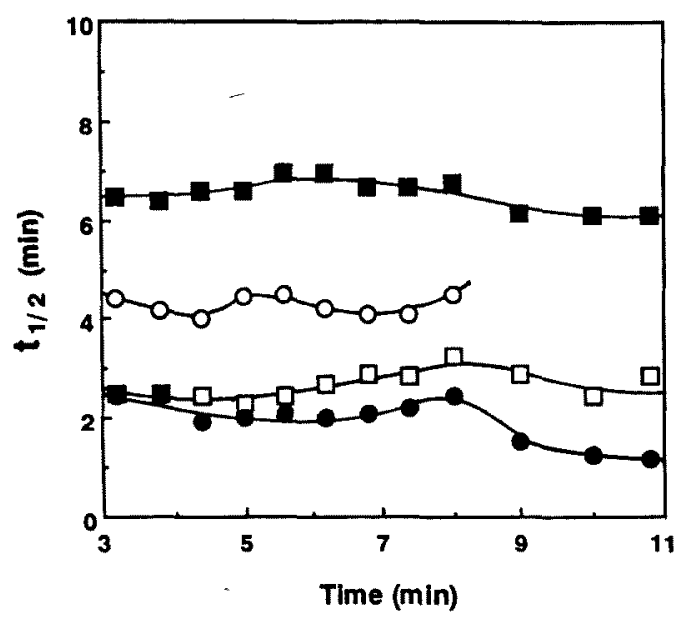

Fig. 5 Relationship between half-life $\left(t_{1 / 2}\right)$ for degradation and $\mathrm{pH}$ in degradation of Orange $\mathrm{I}-\mathrm{N}$ (initial concentration of dyes $=1 \times 10^{-4} \mathrm{M}$ ) with electrolysis under a constant current of $40 \mathrm{~mA}$ at $30^{\circ} \mathrm{C}$ in the presence of $0.1 \mathrm{M} \mathrm{KBr}: \bigcirc$; Orange I, $\mathrm{O}$ : Orange II, $\square$; Orange III, ; Orange $\mathbb{N}$.

$30 \mathrm{~nm}$ 移動する浅色効果が見られ，またオレンジ【ににも 同様なスペクトル変化が見られたことからクロラミンの 生成は考えにくい。分解性の違いは，アゾ基のクロロニ ウムイオンとの反応性の違いによるものと考えられる。 オレンジIII とNは，電子及引性アリールアゾ基に封して パラ位にそれぞれ $\left(\mathrm{CH}_{3}\right)_{2} \mathrm{~N}-， \mathrm{C}_{6} \mathrm{H}_{5} \mathrm{NH}^{-}$基を有し, Ham-

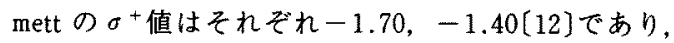
$\left(\mathrm{CH}_{3}\right)_{2} \mathrm{~N}$-基の電子供与性が高い。すなわち，電子供与 性の高い置換基を有するオレンジ而のアゾ基の電子密度 はオレンジNより高く, 親電子性のクロロニウムイオン との反応性も大きく，分解も速いと推察される。

図 5 に，峊素イオン共存下に拈ける染料分解の $\mathrm{pH} の$ 影響を示す。分解は塩素イオン共在下に比べて $\mathrm{pH} の$ 影 製は小さく，オレンジII>III > I > Nの順に分解されや すく，染料の化学構造が分解性に影響していることが示 哱された。次整臭素酸イオンとフェノールレッドとの反 応によりブロモフェノールブルーの生成が知られており [13]，臭素イオンとフェノールレッドの共存下における 電解で，電解とともにフェノールレッドにもとずく可視 部435nm の吸収は完全に消失し，新たに591nmにプロ モフェノールプルーにもとずく大きな吸収が現れ，この 電解によりフェノールレッドは定量的にブロモフェノ一 ルブルーに変化することが認められた。これは，白素イ オンの存在下における電解で次亜奥素酸イオンの生成が
起こることを示すものである。それ故，生成した次亜悬 潔酸イオンから更にプロモニウムイオン $\left(\mathrm{Br}^{+}\right)$が生成 し，このイオンがクロロニウムイオンと同様にアゾ基を 攻整することによりアゾ染料の分解が起こるものと考え られる。臭素イオン共存下の電解に扔いては，理由は不 明であるがいずれの染料も塩素イオンの電解に比べて分 解されやすく，ブロモニウムイオンがクロロニウムイ才 ンに比較して分解能が大きいことがわかる。前述のよう に，ブロモニウムイオンにおいてもHAではアゾーヒド ラソンン型互変異性平衡が分解性に影臂し，ホレンジ IIが Iより分解されやすく，また，AAは置換基の電子供与 性の違いにより，オレンジIIがNより分解されやすいも のと解釈される。

\section{女 献}

1. U. Meyer, S. Kokot, R. Weber, and, J. Zürcher-Vogt, Textilveredilung, 22, 185(1987).

2. L. D. Marahusin, S. Kokot, and D. P. Schweinsberg, Corrosion Sci., 33, 1281(1992).

3. S. Kokot, L. D. Marahusin, and D. P. Schweinsberg, Text. Res. J., 63, 313(1993).

4. S. Kokot, L. D. Marahusin, D. P. Schweinsberg, and M. Jermini, Text. Res. J., 64. 710 (1994).

5. 田村英雄, 松田好晴, 「現代電気化学」, 培風館, p. 219 (1994).

6. C. C. Chen and K. Rajeshwar, J. Electrochem. Soc., 141. 2942 (1994).

7. P. Gregory and C. V. Stead, J. Soc. Dyers Colour., 94, 402 (1978).

8. J. Griffiths and P. Gregory, "Colour and Constitution of Organic Molecules", Academic Press, New York, p. 189(1976).

9. M. Smith and K. Tatchell. "Organic Chemistry for General Degree Students : Vol. 1- Fundamental Aliphatic Chemistry". Pergamon Press, Oxford, p. 120 (1965).

10. D. Kyriacou, "Modem Electrooganic Chemistry", Springer-Verlag, Berlin, p. 171 (1994).

11. R. Ohura, A. Katayama, and T. Takagishi, Text. Res. J., 62, 552 (1992)

12. H. C. Brown and Y. Okamoto, J. Am. Chem. Soc., 80, 4979 (1958).

13. 日本分析化学会編, 「分析化学便覽」, 丸善, p. 299 (1991). 